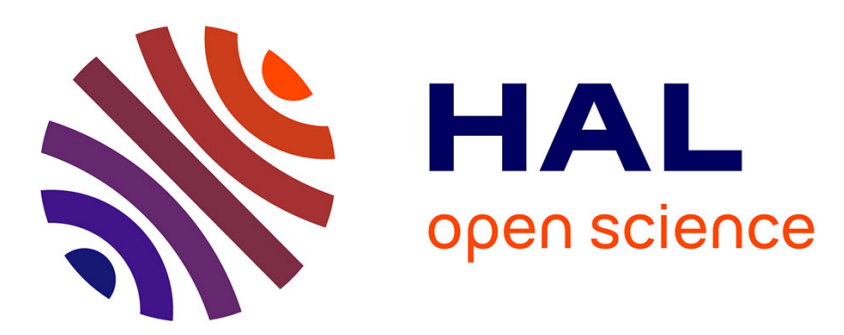

\title{
ADIABATIC SHEARING IN CAST AUSTENITIC STEEL UNDER BALLISTIC ATTACK
}

\author{
J. Krejcí, J. Brezina, J. Buchar, S. Rolc
}

\section{To cite this version:}

J. Krejcí, J. Brezina, J. Buchar, S. Rolc. ADIABATIC SHEARING IN CAST AUSTENITIC STEEL UNDER BALLISTIC ATTACK. Journal de Physique IV Proceedings, 1991, 01 (C3), pp.C3-667-C3673. 10.1051/jp4:1991393 . jpa-00250539

\section{HAL Id: jpa-00250539 https://hal.science/jpa-00250539}

Submitted on 1 Jan 1991

HAL is a multi-disciplinary open access archive for the deposit and dissemination of scientific research documents, whether they are published or not. The documents may come from teaching and research institutions in France or abroad, or from public or private research centers.
L'archive ouverte pluridisciplinaire HAL, est destinée au dépôt et à la diffusion de documents scientifiques de niveau recherche, publiés ou non, émanant des établissements d'enseignement et de recherche français ou étrangers, des laboratoires publics ou privés. 
Colloque C3, suppl. au Journal de Physique III, Vol. 1, octobre 1991

\title{
ADIABATIC SHEARING IN CAST AUSTENITIC STEEL UNDER BALLISTIC ATTACK
}

\author{
J. KREJČÍ, J. BŘRZINA, J. BUCHAR and S. ROLC \\ Institute of Physical Metallurgy CAS, ̌̌ižkova $22,616 \quad 62$ \\ Brno, Czechoslovakia
}

\begin{abstract}
Rêsumệ: Des cibles constituées par des empilements de disques d'aciers austénitiques 18/8 ont êté soumises à des jets de charges creuses avec revêtement en cuivre. Les modiflcations de structures induites dans le matériau cible ont été étudiées par microscopie optique. MET et MEB. Le processus de dêformation est principalement la combinaison de maclage et de glissement de dislocations. Les bandes de cisaillement adiabatique ont un cour sans limites de grains et de macles bien définies entouré par une zone à forte déformation. La densité de dislocations et de macles dans cette zone décroit progressivement en fonction de la distance au cœur. Les taches des diffractions associées à la ferrite ont été rarement observées au cœur des bandes de cisaillement. La taille des grains à l'origine des taches observées est inférieure à $0.05 \mu \mathrm{m}$.
\end{abstract}

\begin{abstract}
Discs from $18 / 8$ austenitic steel were stacked to form targets. The targets vere loaded by shaped charge vith copper liner. Optical, scanning and transmission electron microscopy vere used to evaluate structure changes in target material. Deformation process is mainly the combination of tyinning and dislocation $811 \mathrm{p}$. Adiabatic shear bands have a core where no sharp grain or twin boundaries vere resolved, surrounded by high strained region. Dislocation and twin density in this region gradualiy decreasing with the distance from the core. Rarely diffraction spots corresponding to the ferrite vere observed in the core of adiabatic shear bands. DF images show that the size of grains giving rise to spots are less than $0,05 \mu m$.
\end{abstract}

\section{I - Introduction}

Adiabatic shear bands (ASB) are the subject of decades lasting study and contraversy. Known also as transformed bands, they are usually being connected with high strain rates and of ten it is presumed that they are responsible for the fracture. The partial review of the subject is in /1/. Authors proved that in AISI 4340 steel no transformation occur in ASB. On the other hand they also shoved that ASBs are not responsible for fracture as spal1 cracks traverse ASBs. Armour steel was studied in $/ 2 /$ and author came to the conclusion that equiaxed ferrite grains in ASB are the product of heating to the temperature where delta-ferrite exists. It is really difficult to accept authors use of phase diagram for explanation of structure changes in ASB. Condition existing during the formation of ASB are so far from equilibrium that phase diagrams are useless. Moreover thermal hysteresis is often being neglected. On the other hand it is clear that the response of different materials to high strain rate /3/ (or high strain low rate) differs considerable and it is necessary to acquire more experimental data before general conclusions about the nature and origin of adiabatic shear bands may be done. 


\section{II - Experimental nethods}

Discs ( $110 \mathrm{~mm}$ in diameter, $55 \mathrm{~mm}$ thick) fron $18 / 8$ austenitic stee $1(0,09 \mathrm{C}, 0,16 \mathrm{Mn}, 0,47 \mathrm{Si}, 0,13 \mathrm{Mo}, 18,6 \mathrm{Cr}, 8,5 \mathrm{Ni}$, all wt\%) were mashined from 40kg casts. The discs were stacked to form target, eventually armour steel plates vere used to lover impact velocity of the incident fet. This velocity was approximately $8000 \mathrm{~ms}^{-1}$. Shaped charges had copper 1 iners.

Optical microscopy, hardness test, SEM with X-ray microanaI isis and TEM vere used to evaluate different aspects of the perforation process. Thin foils for TEM vere prepared by ordinary jet method in TENUPOL. Thinning of ASBs and surrounding matrix was posing no great problems. Thin foils were examined in Philips CH12 microscope at $120 \mathrm{kV}$ accelerating voltage.

\section{III - Results and discussion}

Original structure of specimens (discs) was as cast i.e.
dendritic with eutectics in some interdendritic regions. The effects of perforation by shaped charge jet can be divided into large scale and microscopic.

$A$. The specimens vere veighed before and after the test. The veights of individual specimens vere the same or larger after the perforation. The gain in the veight can be attributed to the material of shaped charge jet caught on the surface of the hole. The surface of the perforation was irregularly covered by the layer containing both copper and elements of the target material.

The width of the perforation is fluctuating along the axis of specimen. Prevailing direction of macrocracks vas parallel with specinen axis, approximately $10 \mathrm{~mm}$ from the surface of the hole (i.e. $25 \mathrm{~mm}$ from the axis of the spectmen). The macrocracks had no apparent affintty to the interdendritic regions and it is possible to assume that they are the result of reflection of shock waves at the side surface of the specimen.

The hardness was measured in lines perpendicular to the surface of the perforation. The values of hardness (HV1) are increased in whole volume of discs in comparison with original hardness (before the test - 170 HV1). The hardness is decreasing from the region near the surface of the perforation (around 400 HV1) on first $20 \mathrm{~mm}$, ramaining constant ( 240 HV1) to the outer surface of the specimen. Similarly under the bottom of the perforation in specimen where jet was stopped hardness is increased in whole remaining thickness. Maximum value of hardness is slightly decreasing along the jet path.

B. On the microscopic scale three phenomena can be observed: 1. Localized deformation in the form of deformation bands especially in the vicinity of defects (voids, inclusions).

2. Interdendritic regions near the perforation are changed - they lost their lamellar character and seems to be structuraly homogen i ous.

3. ASB are frequent around the hole, their number falling toward the outside surface. Their shape and direction have no apparent relation to the structural elements (Fig.1). ASBs are cracked on$1 y$ in the surface layer adjacent to the perforation. Cracks are usually connected with hole surface and they are therefore filled with material containing copper.

The thickness of ABSs observed on etched surfaces is around $1 \mu \mathrm{m}$. More precise meauserment is not possible due to the etching effects, moreover we cannot be certain that ASB was cut at $r$ ight 
angle.

The structure of target at distance from the penetration surface equal to half diameter of specimen is in Fig.2 along vith corresponding selected area electron diffraction. All SAD vere recorded with the diaphragm which restricts diffracting area to the circle with $2 \mu \mathrm{m}$ diameter. Fig.2 shows that deformation nechanism is twinning combined with dislocation slip.

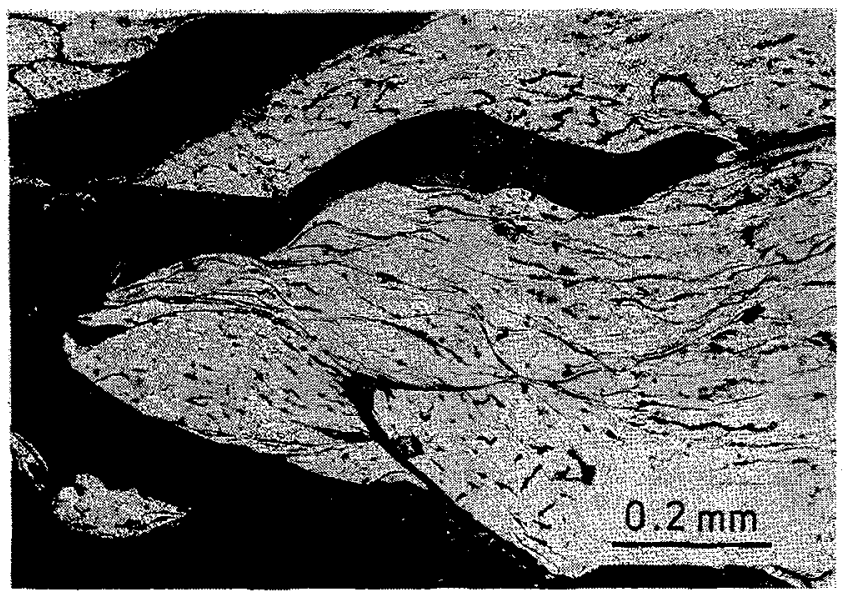

Fig. 1 Cross section of perforated disc. Surface of the hole is in the lower left corner.
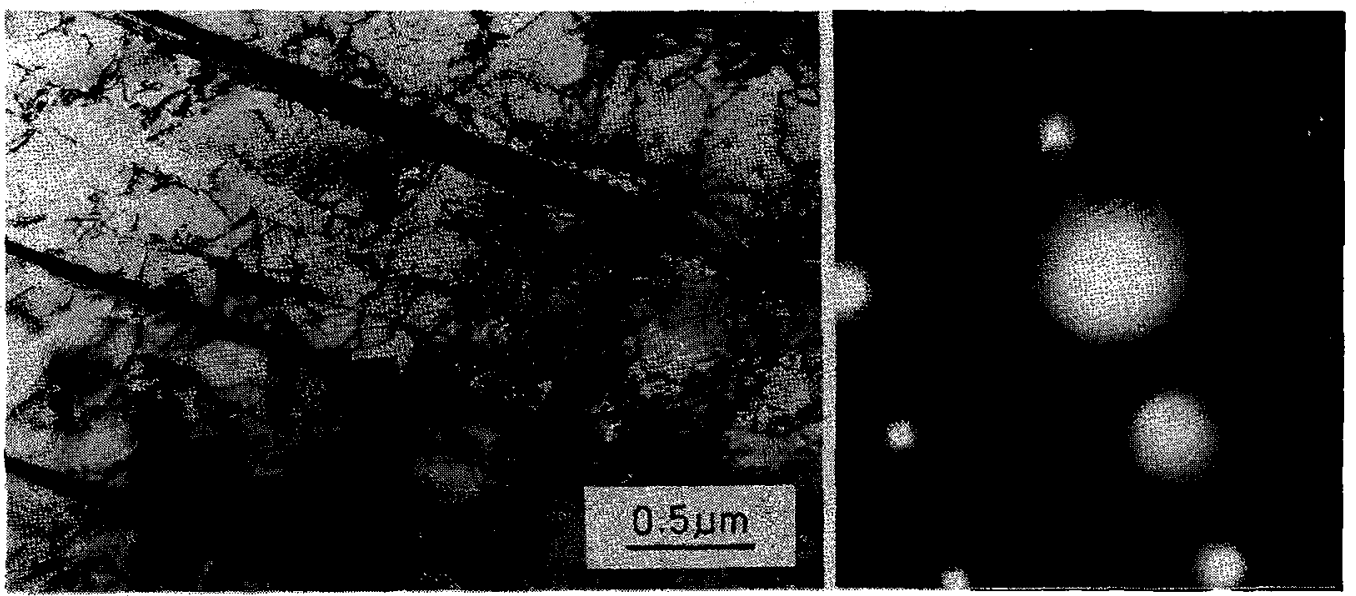

Eig.2 Structure in the middle of the specimen. 

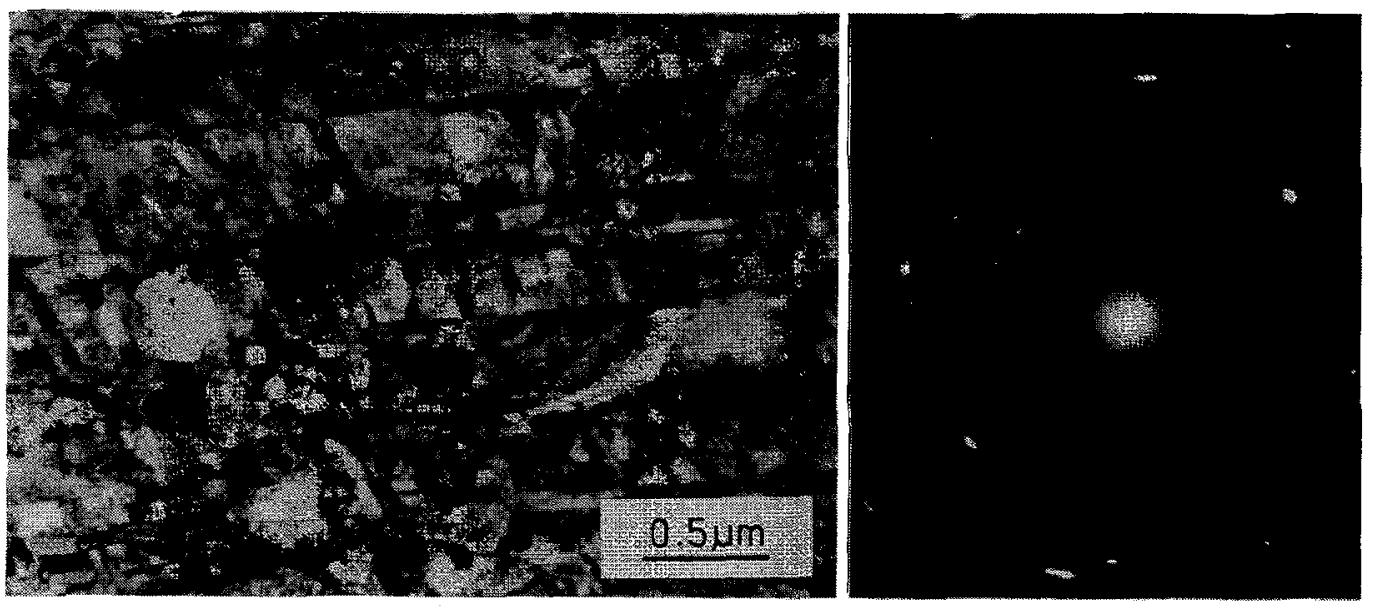

Fig.3. The structure near the perforation.

This figure represents the heavily deformed structure near the surface of perforation. High density of twins as vell as dislocations is characteristic for this region. SAD prove higher disorientation.

The core of adiabatic shear band is approximately $2 \mu \mathrm{m}$ thick - Fig.4. This figure was taken in STEM - DE mode. Detail of the core boundary is in Fig.5. The boundary is not sharp - the "melee" of dislocation valls is irregularly connected vith boved twin structure.

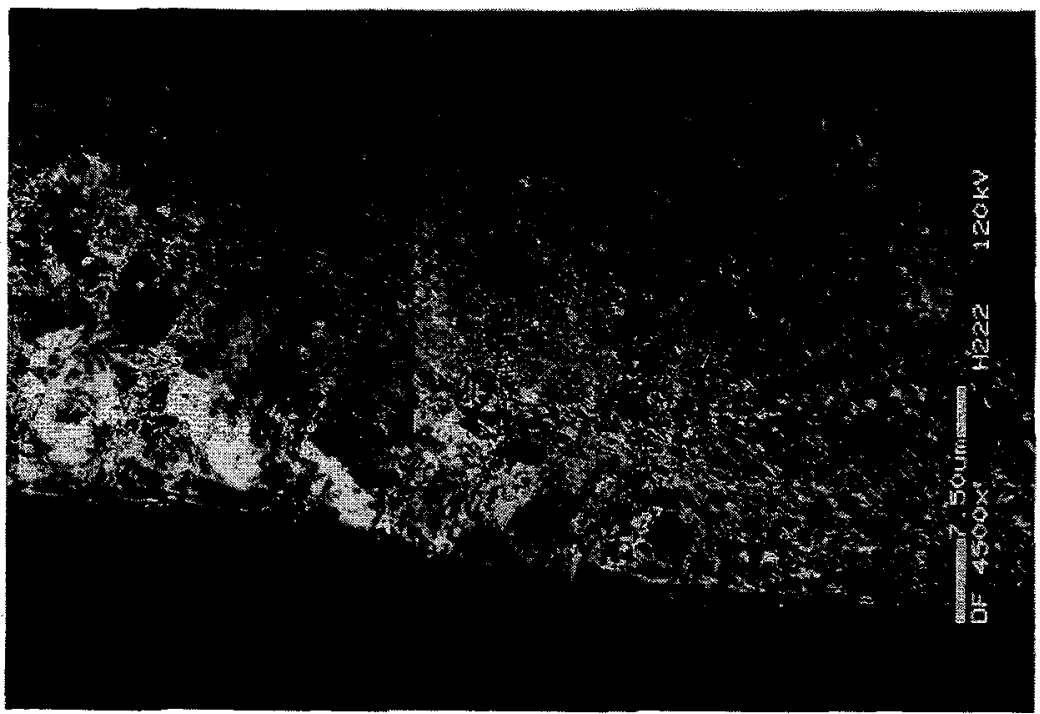

Fig. 4 STEM - DF inage of the ASB and near structure 


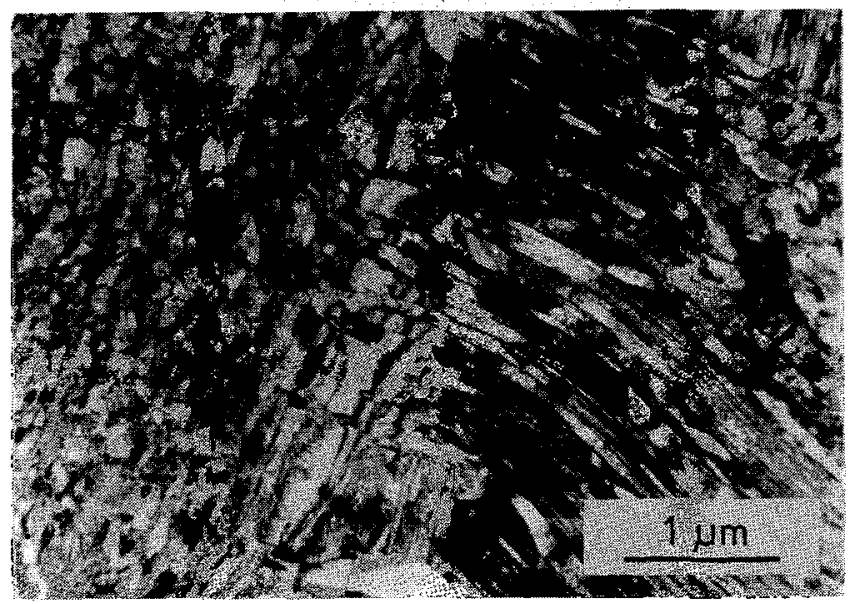

Fig.5 The boundary between core and outer regions of ASB.

Details of the core structure are in Fig.6. These micrographs are from different regions of the ASB showing that in some orientations the structure is elongated. It is clear that core structure contains high dislocation density (dislocation valls) but twin are less numerious. Disorienta- $t$ ion in the core is very high (Fig.7).

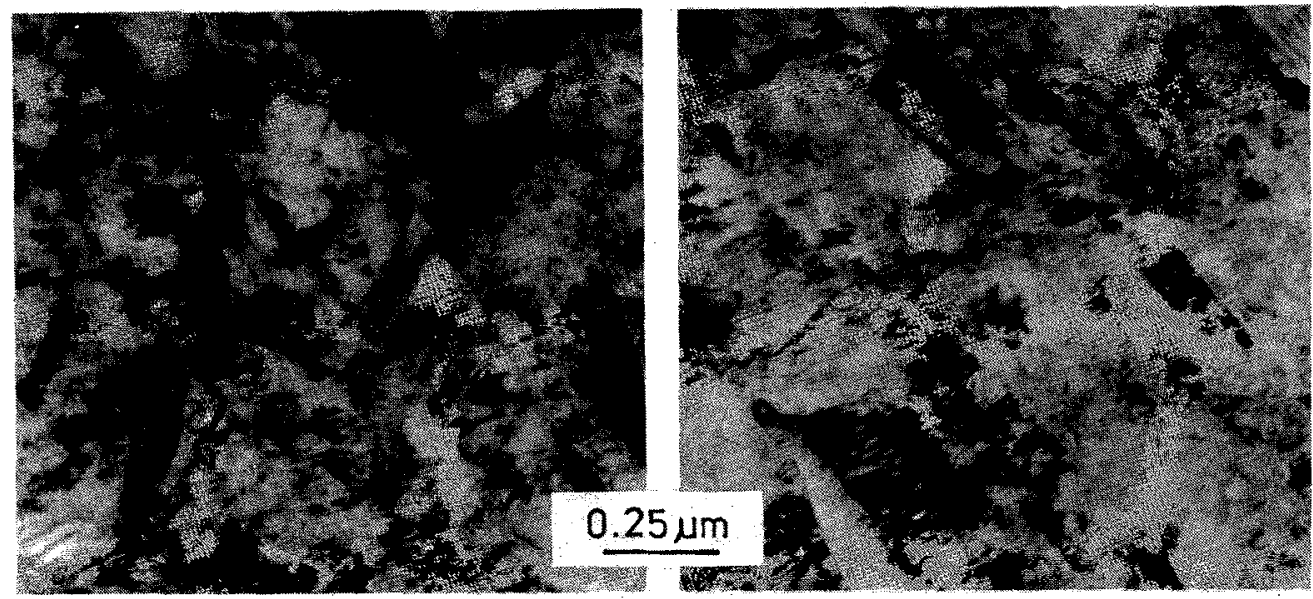

Fig.6 The core of ASB in two different orientations

In sone cases diffraction spots (arcs) which do not belong to the FCC austenit pattern were identified in SAD. They fit into BCC ferrite pattern (as far as it can be concluded from individual spots). In Fig.7 bright field, SAD and dark field in diffraction not belonging to the FCC pattern are presented. 

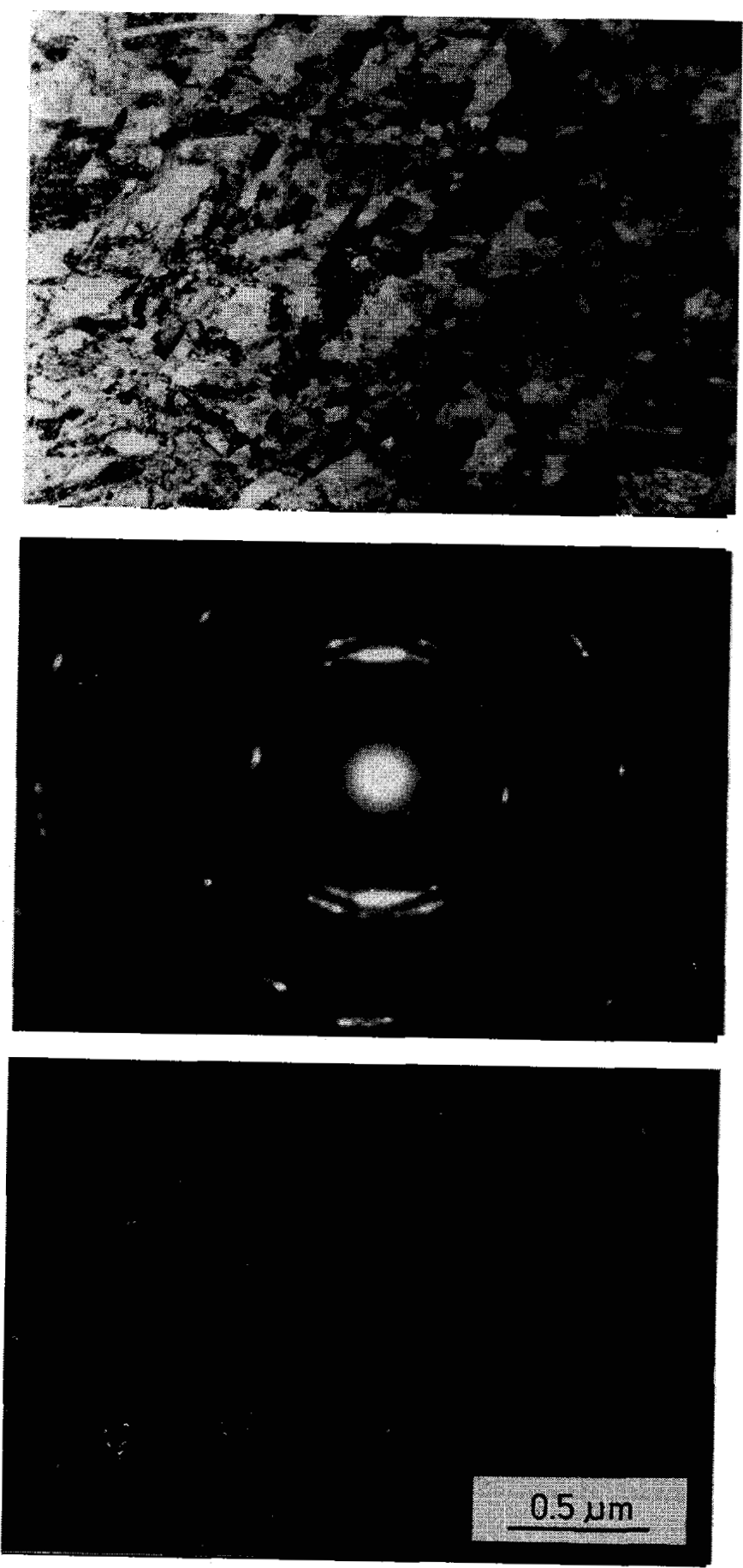

Fig.7 Bright field, corresponding SAD and dark field image obtained using marked spot. 


\section{IV - Sunmary}

ASB in austenite loaded by shaped charge (incident velocity of jet was $8000 \mathrm{~ms}^{-1}$ ) can be described as very thin core $(\approx 2 \mu \mathrm{m})$ containing highly disoriented grains (subgrains) with size less than $0.1 \mu$, high dislocation density and few twins. Occasionally ferrite could be identified. This thin core is surrounded by heavily deformed region with high density of twins and dislocations. The density of these lattice defects is gradually decreasing with distance from the core of ASB. X-ray microanalysis did not show any differences between composition of ASB and matrix.

In accordance with the results quoted by Hatherly and Mal in 14/. no traces of rearystallization. which would prove that temperature was significantly rised, were found.

Small width of ASB in the austenite is in qualitative agreement with theoretical evaluation of Dodd and Bai /5/.

\section{References}

/1/ MITTMAN C.L., MEYERS M.A., PAK H.-r., Met.Trans. 21A (1990), 707

/2/ DEREP J.L. Acta Met. 35 (1987), 1245

13/ GERLACH U., Met. Trans. 17A (1986), 435

/4/ HATHERLY M., MALIN A.S. . Scripta Met. 18 (1984), 449

/5/ DODD B., BAI Y., Materials Sci, and Techn. 1 (1985), 38 